УДК 351.851

DOI: $10.21564 / 2075-7190.46 .213229$

Juan Guillermo Mansilla Sepúlveda, Research Professor Education Faculty of Catholic University of Temuco, Chile e-mail:jmansilla@uct.cl ORCID ID: https://orcid.org/0000-0001-8175-7475

Claudia Andrea Huaiquián Billeke, Research Professor Education Faculty of Catholic University of Temuco, Chile e-mail: chuaiquian@uct.cl

ORCID ID: https://orcid.org/0000-0001-9188-3264

Juan Guillermo Estay Sepúlveda, Research Professor

Education Faculty of Catholic University of Temuco, Chile. Education Faculty of Adventist University of Chile, Chile e-mail: juanguillermoestay@yahoo.es

ORCID ID: https://orcid.org/0000-0001-7348-5529

Germán Moreno Leiva, Research Professor Faculty of Health Sciences of University of the Americas, Chile e-mail: kinegerman@gmail.com ORCID ID: https://orcid.org/0000-0001-5338-0391

\title{
INTERSUBJECTIVITY AND POWER IN THE ADMINISTRATIVE LEADERSHIP OF HIGH SCHOOLS
}

Findings of a qualitative research developed from a hermeneutic paradigm are presented. This paradigm is related to the dynamics of power that underlie teachers' discourse about the asymmetric intersubjective relationship which appears between headmasters and teachers of high schools from the Arancania region at the South of Chile. The participants were 14 headmasters and 48 teachers. Data collection was made using focus groups with headmasters and in- depth interviews with teachers. Data reduction was made though the coding process, open and axial, using the Atlas Ti 6.2 software. Findings show the existence of an intersubjective relationship which evidence exercising the power and control from the headmasters towards teachers. Furthermore, there is violence in the mechanisms that are articulated from the administrative organization. Participants recognized the systematic discursive practices of symbolic violence, which damage their professional quality, in the action of headmasters of high schools.

Keywords: Intersubjectivity, high schools, power, oppression, teachers.

(C) Sepúlveda J. G. M., Billeke C. A. H., Sepúlveda J. G. E., Leiva G. M., 2020 
Research problem. The purpose of this research was the following: to show the mechanisms of power that are used systematically by headmasters of high schools to control the curricular and administrative actions which are developed by teachers in highs schools located at sociocultural places of high social and economic vulnerability. The mechanisms of power used by headmasters stealthily move a great volume of symbolic violence, as much in the discourses as in the quotidian practices at the high school. The research was based on the premise that every exercising of power which reaches to impose meanings to others intelligibly transmits, and with a sophisticate dissimulation, the relationship of force, which is justified in its own force. It means, it exactly is symbolic to the intersubjective relationships that are given between the members of the same community [1]. The exercising of power since the discipline and punish has an epistemological milestone, which is relevant in the work of the French philosopher Michel Foucault [2]. At the same time, the problem of power is connected with the problem of the use of discipline on the human bodies and their corresponding submissiveness, which is the result of the compulsory understanding of regulations, rules, disciplines, schedules, logics, tools and tasks with a microphysic level $[2 ; 3]$. In the intersubjective relationships in the field of education, there is a social scene where the relationships of power are constantly in practice. For that reason, it unleashes undesirable acts. For example, the treatment that the teacher receives by the authorities and the different subjects, who participate in the educational community: students, colleagues (other teachers), supervisors, employees, authorities, among others, where the power is exerted in different ways and positions. When the ensemble of these mechanisms makes synergy, it produces an invisible panopticon. The empirical evidence shows that teachers reveal highest level of stress than other professional due to the different systems of pressure/ oppression that exist on them [4-6].

The reality and the historical experience founded on different researches emphasize the existence of residual fatigue, general malaise, psychological sufferings (depressions, anguish, panic attack and psychotic processes) and different ways of physical ailment, which appear from loss of voice, pain and muscular contraction on the back, neck and limbs, stomach ulcer, hypertension, among the most common. Recently, diabetes caused by stress is registered with a high frequency [7]. In the shelter of what was said before, the question that guides this research was: How is revealed the intersubjective relationship between headmasters and teachers from high schools located at the city of Temuco, Araucanía region, Chile?

Theoretical framework (Conceptual Framework). In this research epistemological categories are intertwined, which sink their roots in the theoretical analytical traditions with a systemic, dialectic and genetic nature [8]. In that regard, stand out the social- historical- cultural theory founded by Lev Vigotsky [9] specifically the zone of proximal development, which refers to the social construction 
of knowledge, competences and identities $[10 ; 11]$ communities of practice $[12$; 13], and the third generation of the activity theory and the expansive learning with the inclusion of inter- institutional activity systems $[14 ; 15]$, the habitus theory and symbolic violence by Bourdieu; and the tradition of the power theory $[16 ; 18]$.

The concept of symbolic violence is related to what Bourdieu [1] calls «theory of the cultural reproduction». Reproduction is understood like the way that some values and meanings are reproduced between social classes. These meanings are reproduced from the top of the hierarchies with some specific purpose that is in advantage for this group of power. These concepts appear «naturalized» and perceived like normal by who are affected by this force. This kind of power relationship could be reproducing since many years ago, in a hidden way and has been unnoticed due to the scant and non-existent resistance of who are forced, or as Foucault [17], points out by means of the institutionalization. This will be the case of schools, prisons and hospitals, all of them institutions with the same nature, according to the proposal of this French philosopher. The institutionalization of the symbolic, instrumental and indirect violence causes that the violence facts or the exercising of symbolic power is perceived like «part of the job», so to speak. That is why the violence reaches to be invisible and even it reaches to disappear from the conscious universe of the individuals, placing itself in a pre-predicative scene in the everyday lifeworld [19]. People affected by the institutionalization do not argue, they assume an obedient vassalage and they do not realize or they perceive the violence facts like something natural from the educational field even in some circumstances they are the same people. In this case, teachers themselves are who justify the violence acts when they do not affect them. In this pedagogical action is where the social reproduction of power is produced in a forceful way. The pedagogical action is objectively a symbolic violence, the extent that they instill imposed meanings which introduce the selection or exclusion like cultural arbitrariness, since a group instills the acceptance in others, and it also instills rejection, but not the annihilation of the arbitrariness. Profits gain in a battle field can be used like resources for others fights. The pedagogical action needs the pedagogical authority as social condition required to exert power, which is exerted in a relationship of asymmetric communication in educational places that produce its own symbolic effect. The extent that the arbitrary power makes possible the imposition, it does not appear in its truth, but as inculcation of a cultural arbitrary which makes possible the hiding of the symbolic power. This happens in an everyday intersubjective relationship between who have to manage the institutions and who have to carry out the instructions given by the educational leaders.

Nietzsche shows as the language imposes a new order to the world. Since its most instrumental conception, the language represents symbolic violence and it constitutes the means by which the will of power can decide what is good or what 
is bad, what is true or what is false [16]. To Bourdieu, the educational subject is a radical problem of control from the symbolic capital. Therefore, there must be developed new ways of combat to resist suitably the violence from the symbolic oppression which is exerted by the institutions and organizations that usurp the power. Habitus is pre-thoughtful structure which influences that the agent is ready to the action. It assures a practical control of uncertainty situations, and at the same time, it founds a relationship of practice in advance, because it discovers in the objectivity of the world the future gain like a contingent and indeterminate future [20, p. 22].

Likewise, since the humanist theory specifically the trans-analysis, it expects to explain the different ways of energy liberation inside the human body and which in an institutional level have been repressed and constricted. In that way, the libidinal body (inhabited by free energy) is transformed into a productive body. In that regard, Lapassade [21, p. 70] based on Reich's theory of the energy, he explored new forms to find a synthesis between this two movements. The trans-analysis is conceived as an action in which the natural and constructed dimensions allow to explore and work the energy dialectic of the difficult relationships between what is introduced and what is constituent, it is between the social tied energy and the social free energy. The liberation of the cuirass of the register violence on the libidinal body, that is imposed to the man because the domineering social order, will allow to the man to install a new order, without servants, without structural violence, without asymmetry nor violence. This involves overcoming the current pedagogical paradigms valid in Chile and Latin America regarding to the meaning that high school has, whose pragmatic main focus is blocking by the standardization, measuring, control, surveillance of the results and administration. In conclusion, it is an exploitation of the practices, where the academic performance is a means to reach social and cultural control having like a focus the national syllabus with a prescriptive nature. According to the previous, this challenges to the actors of the educational system to change into critical, liberating, not-violent and peaceable beings and above everything conscious beings of the intersubjective scheme where they are inserted and where they construct their meanings.

Method. This study is placed in the qualitative research [22]. It has like general objective the study of the activities and subjectivities that construct the everyday life world (lebenswelt), considering the reality like multiple and the truth like meanings, looking for the comprehension of the phenomenon and applying a method that considers the analysis of the meanings, recognizing the interaction subject and object like inseparable, valuing those data that emerge from the subjects themselves. The paradigm that guides this research is the tradition of the symbolic interactionism which gives an essential importance to the «social meanings constructed» $[23$, p. 24]. The level of the research is thick description. It means 
that, the fundamental task was not only coding the abstracts regularities, but also making possible the thick descriptions of peoples' life, not only generalizing through cases but also inside them, in an emic way [24]. The method of sampling used was non-probability. Thus, the strategy to select the participants was intentional. There were 48 teachers researched, who are distributed by 14 particular high schools which receive subsidy from the government from the Cautín province, in the Araucanía region at the south of Chile. These high schools are located at context of high social and economic vulnerability. Semi-structured interviews and four focus groups were used for data collection. The verbal data that emerged from the interviews were reduced by means of the coding processes. It is highlighted the first moment, the open coding, from which the first categories raised from the phenomenological inductive processes. Categories were enumerated consecutively following the order of the data collection, from their recurrence, intensity and illocutive force of the story. It had like criterion the symbolic quality. Subsequently to this process, a description of the categories was made looking for the models of the theoretical framework and the matters that emerged from the subjects themselves with constant comparative method (CCM). The findings found were described by each category; then by means of a network were identified the relationship between categories, reaching a second level of coding, the axial coding. This kind of coding allows to building conceptual networks which summarize the fundamental concepts and their relationship, which are described. Finally, a qualitative content analysis is applied to reveal the matters that appear from the data [25]. A qualitative content analysis was made, it relates to «any reduction of qualitative data and sense effort of decisions that carries out a volume of qualitative material and the attempts to identify the basic consistency and meanings» [26, p. 453]. Verbal data systematized allowed us to justify the arguments about our statements of knowledge, which emerged from the empirical-theoretical sampling of the codes displayed from each category interpreted [25]. Regarding to the criteria of scientific rigour, it were used credibility (verification of the truthfulness of the findings); transferability (the guarantee that the findings can be applied to other contexts and other participants); dependability (to ensure of the internal consistency of the findings), and confirmability (to confirm that the findings are the result of the research and they are not distorted by the researcher's bias. These criteria are applied to ensure the reliability of the study [27]. The credibility was presented by means of the triangulation of the methods used by data collection. The transferability was reinforced by the intentioned selection of the participants and the different high schools in order to guarantee the visibility on the text of a diversity of voices. A thick description was developed of the result in order to other researchers could establish meaningful comparisons. Transferability and confirmability of the research findings were presented leaving an ample trace 
of inspection of the process of data collection from the empirical sampling of the material that were reduce to codes in the each conceptual network.

The ethical dimension, as suggest Babbie y Mouton [27], Henning et al. [25] and Terre Blanche, Durrheim and Painter [28]. It was considered the care of keeping the protection of the privacy of the participants and to deal with sensitivity their right of anonymity. It was respected the reliability and the voluntary participation previous signing of the informed consent. It allowed to that the interviews were carried out in a setting of a relationship of confidence, rapport and transparency. Finally, it should be pointed out that this research is assigned to the Declaration of Helsinki and the Declaration of Singapur.

Results and Discussion. Coding of data was made with qualitative software Atlas $\mathrm{Ti}$ 6.2. The following analysis categories were raised: normative impositions of work, subtle pressure, hierarchical impositions of goals, direct supervisions, circumstances and authority, demands of deadlines and documents, differentiation administrative- teachers, invasion of the pedagogical space and deficient municipal system.

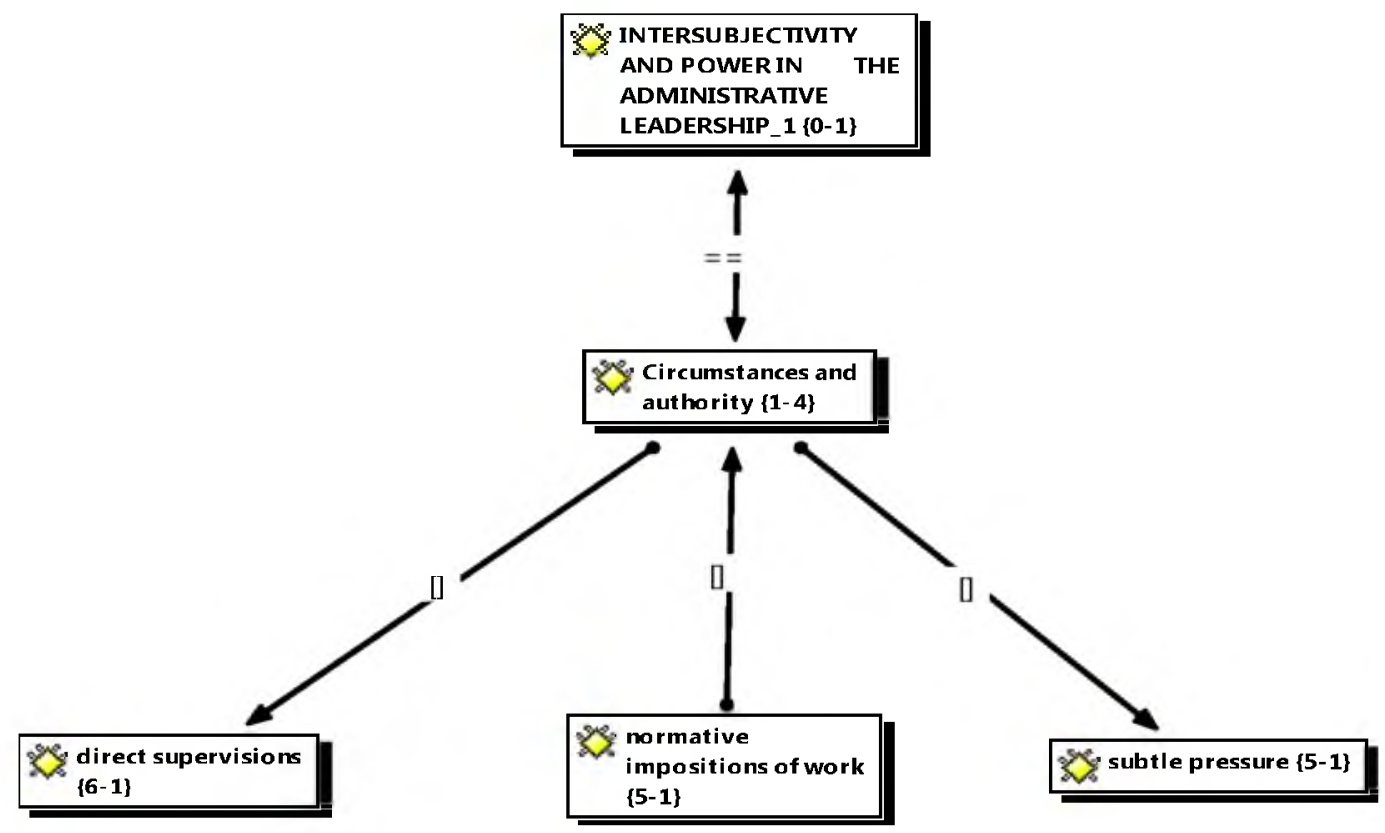

Network 1. Circumstances and authority

One of codes of the «circumstances and authority» category corresponds to the «normative impositions of work». These are part of the circumstances where teachers daily develop their work at the educational institutions. In Chile it is important to highlight the existence of a deficient municipal system, which is 
currently questioned by the different actors of the educational system. In this context, there is the perception of the existence of direct supervisions and subtle pressures. In addition to the annoyance that teachers can see for the invasion of the pedagogical space. The code «hierarchical impositions of goals» shows the symbolic violence through the imposition of the contents that must be taught, which is generally related to the achievement of curriculum coverage according to the national syllabus. The previous can be reflected on the following fragment of the interviews: "There 're some goals that must be achieved (...) and those goals must be achieved by us, and we have to achieve them with the students. It means, it's a scale, where everybody must achieve the goals, so the goals of those who are upper (...) can be achieved, and to achieve good results on the SIMCE, it's the main goal and one of the criteria [11, p. 222].

The code «direct supervisions» of headmasters shows the vertical communication that is established between headmasters and teachers, exerting a «subtle pressure» of power in the shelter of relationships of force which are imposed on one of them and supported by the institutionalization.

This supervision is not always made in a direct way by the headmaster of the high school, also through the pedagogical coordinators, who are called «bosses of the technical pedagogical units) too. The relationships are articulated on a complex network of stress and mutual understanding whose sense cannot be recognized by those who do not have the necessary habitus that the game of power between asymmetric forces demands $[29$, p. 26]. In that regard, one of the interviewee emphatically said: "To demonstrate, the specific question, is (...) I think that how to demonstrate must be almost with direct supervisions (...) by means of direct interviews, interviews with the students, and if the classes are observed the professional judgments must be done in the shelter of different visits to the classroom, and not only since the observation, because it's not the observation of the whole class (...) Another thing is that who supervise you must have more studies than you, sometimes de bosses of the UTP supported themselves by the newly graduate students who doesn't reach to understand what means a class, what is also taught in the framework of the hidden curriculum ".

In this conceptual network, nowadays in Chile there is a discussion about the ways of action that headmasters of schools and high schools must have. From a new model of education it means to recognize the administrative functions like supervision, coordination and orientation of the education. It brings tuition and additional responsibility on the teacher staff, teacher's assistants, administrators and professionals of the education [30, p. 67]. Additionally, the category «invasion of the pedagogical space» shows the friction made between the teacher role and the collaboration given by others professionals external to the field of education. On that subject one of the interviewees said: "They aren't mainly involved (...) so 
when I see this (...) when they, for example, have to make changes in the work form eh (...) changes of structures of communication for example, or the referral of the bureaucratic channels that the institution has ... eh / but it results invasive, I think that there 're a lot of requirements too, which we have to achieve, we can 't complain about everything, but the detail is how they ask us the things, because when a headmaster at the end of a meeting he finishes with the question, do you agree?, you can guess what the teacher staff answers, of course we agree, because if you disagree it means that you will be on the black list, that is our trade [12, p. 23]. The code that presents the duality of positions inside the school shows us like evidence how the differentiation between administrators and teachers make a reproduction of the symbolic power, given an institutionalized- administrative violence [31]. The empirical sampling shows this situation in the following fragment of the interview: "I mean I'm hypothetically speaking because it hasn't happened to me, I mean I think that the administrators boss UTP, I don't know // management of who are in a status or hierarchy higher than us» [9, p. 97].

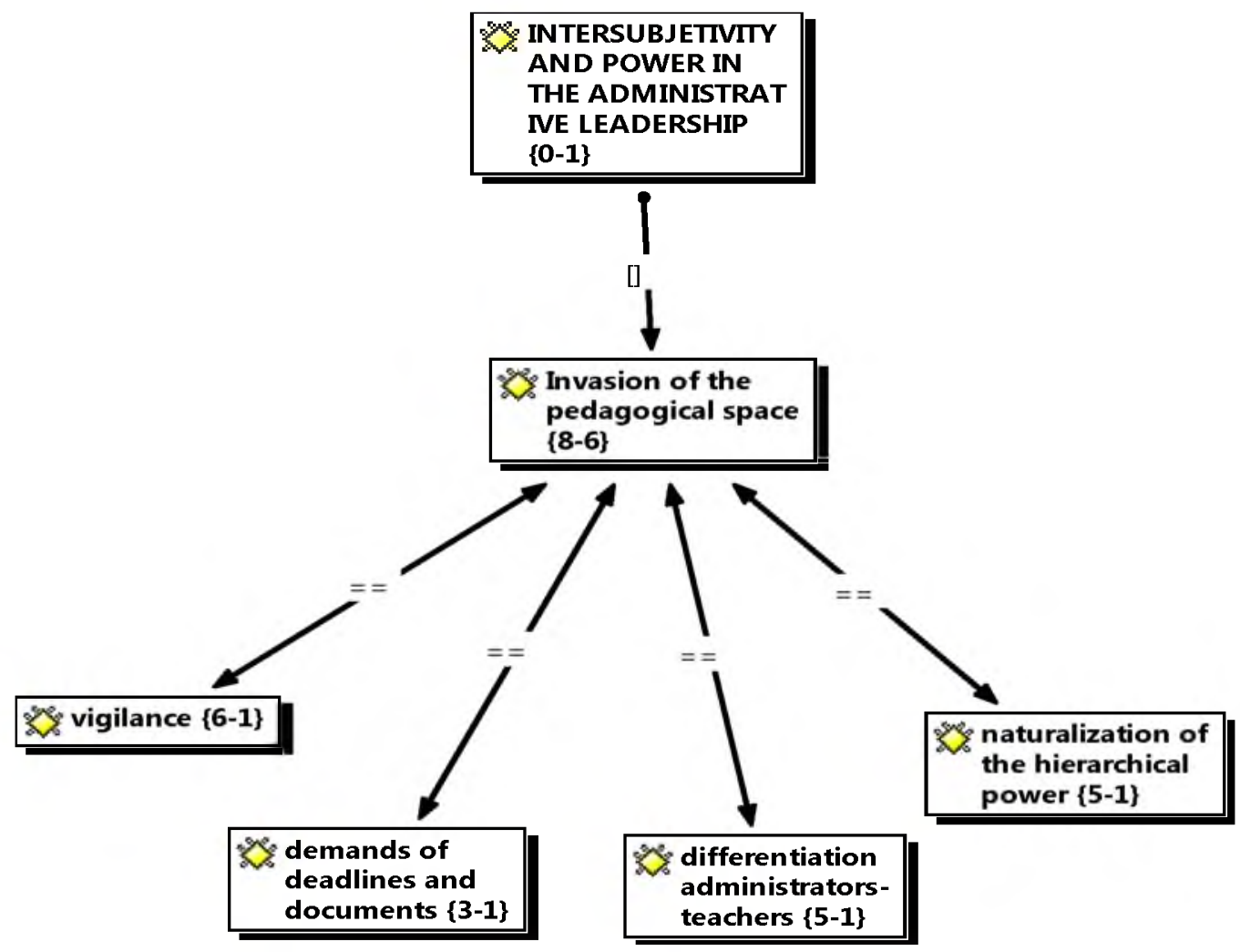

Network 2. Invasion of the pedagogical space 
The headmaster figure has been criticized by Sennet [32], who says that they exert the power without having to introduce themselves as responsible. He reaches to spread this responsibility by himself, putting again the disaster of the job on the shoulders of his victims, the teachers and- what a coincidence- they work for him.

The current educational system established by the new political lineaments valid in Chile allows that the teacher will be regularized by means of his lesson plans, because in that way the public politics of the Chilean educational system are promoted, doing his work in a prescriptive, methodical and instrumental way, giving way to this mechanism of power will be supervised by state agents, thus developing symbolic violence in the demands of deadlines and documents. A teacher says: "Let me see, at the administration level towards teacher when we are demarcated in some goals that we must achieve every semester or every year everything what is, - they require us a lot- the percentage of attendance, the level of promotion I must achieve some statistical numbers to contimue working in a kind of school like we 're now, and also the require us to keep to schedule of hours of collaboration, and what do we do in those hours? From caring from students in the break to check thousands of tests and homework, everybody crowd into the teachers' room very, but very small» $[11, \mathrm{p} .78]$.

What was said before belong to the municipal system which is in crisis, such as one of the teachers interviewee expressed: «Yes, the municipal system is savagely bad, very bad; should be another system, ah? It comes from a vicious cycle, it starts at home:::, not at schools, and it isn't only that the achievement of our students is bad, it comes from many years ago and I think that the system is going to be difficult to change it, you must remember that the reform we have now is a Spanish copy that didn t work in Spain (interviewee close her eyes and smile) we are implemented something that $: .:$ that's not in accordance with our realities, it's like a new form of colonization» [1, p. 76].

It is not only violence the alteration to the existing order, but also in the established order [33]. The educational context is related to the deficient municipal educational system since different aspects. On one side, teachers from municipalized schools are those who receive significantly a higher level of work demands in comparison with teachers from particular schools that receive a subsidy from the government, but at the same time they present some contractual immobility, because they are protected by the Teachers Statute, which impedes that those teacher, who permanently are questioned, will be fired. In this context the main fragility is which affects teachers who are working with part-time contract. Another factor that influences in teacher's malaise is due to the circumstances of the social context in which they are immersed. Where almost a third part of the interviewee teachers said that he/she has been threatened or affected by acts of violence inside the school, 
especially by headmasters, and in some occasions, by students or by their families. At the municipal schools we can see worst characteristics of infrastructure, higher level of violence and high vulnerability and poverty of the students who attend every day at school [34]. In this sense it is interesting to expose the thesis of Santos Guerra [35] who says that «a hierarchical vision of the administration, descending, authoritarian is little coherent with the educational nature of the school. It is because school must teach citizenship. And the citizens think, decide, participate and demand». From this premise, the citizens are not professionals of the obedience, but they are professionals of the agreement.

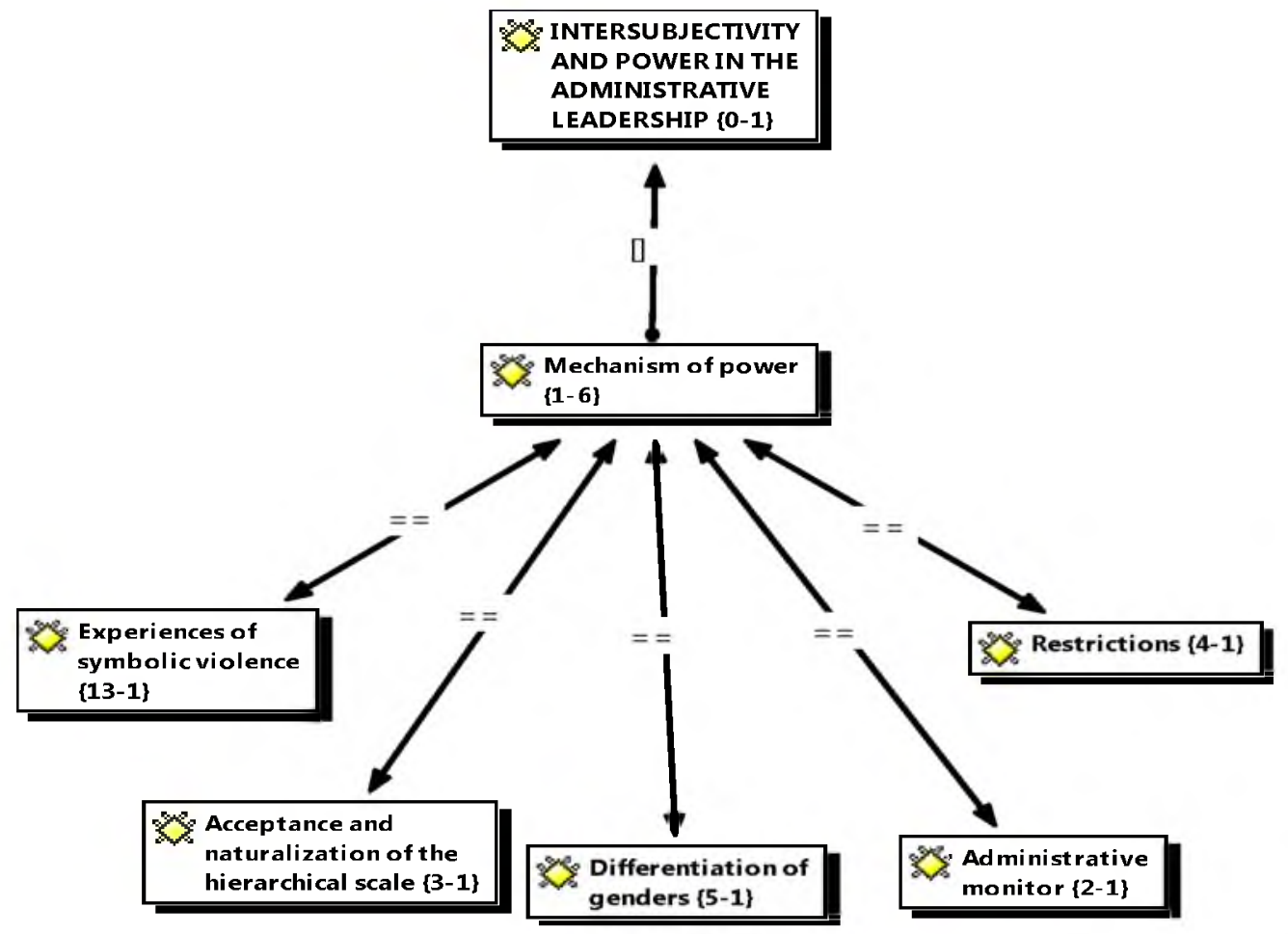

Network 3. Mechanisms of power

Another dimension analyzed was the mechanisms of power present in the intersubjective relationships between headmasters and teachers. The codes raised from this dimensions are: questioning of the teacher's job, violence between genders, acceptance and naturalization of the hierarchies, vigilance, administrative monitor and restrictions. This dimension shows the perception of teacher in relation to the mechanism of power that influence in the concretization of the symbolic violence as well as situations in an environment of propitious factors to generate asymmetry in the relationship and how these affect the subject of study in his/her 
professional and personal context. From the current educational system are generated situations that show slyly the exercising of power, which change its way depending on the place and the circumstances where the subject of study is [1]. One of the interviewee shows that in this way: "Let me see, I think that in this moment at the high school:.:; I think that they're keeping an eye on us, «everyone» every colleague knows what he/she have to do, but in private schools or schools that receive a subsidy from the government the reality is different, it seems like they aren't watching you, but they're always aware of the time you arrive, the time you leave the school, I don't know if in other professions things are like that, but it generates a bad job environment, because it seems like they don't trust me, if you do the thing right nobody say you nothing, but if you commit a mistake everybody, everybody knows, we are really exposed» [1, p. 78].

To present the code vigilance, one of the interviewee says: «I've worked in two or three schools where if they see how you work the first months, then they leave you freely to do what you have to do, nothing else, and the way they control you is through the lesson plans and now they are requiring us daily lesson plans, all in all the piece of paper supports everything (He laughs)» [12, p. 56].

In relation to the hierarchical naturalization, teachers say that they are under the watchful eye of the administrators when they start an activity at school with the category of «new or beginner») inside the educational community. It presents a questioning of the teacher's job that the new member of the teacher staff starts at some school, such as is shown in the following textuality: "Where are you from? Who do you know? How did you arrive? How did you know about the job?, at the first time you're very questioned, but when you:: you start working with your students, you work, you'll have a good relationship with your colleagues, you don t have to make new friends, but you have to share with them, it's difficult to do new things because little by little the educational cultural absorb you» [12, p. 67].

The code, mechanisms of power, is transmitted by means of the constant intersubjective relationships at high schools. It makes operational the mechanisms of power that form, regulate and make the teacher obedient. In that way teachers will act appropriately, such as lesson plans, schedules, transfer of contents to students: "I've been working here for six years (...) but yes, yes, at the beginning I didn't have support like newly graduated and yes, there really are some ways of control . . e ehmm (...) control at the time you arrive at school, control when you leave school . . . in the contimuous revision if the contents have been taught, they checked my notebooks, they asked them at random " [3, p. 43].

The code «acceptance and naturalization of the hierarchical scale» shows how every teacher has internalized the fact that he/she is subdue imposed rules without having the right to give her/his opinion in some occasions, showing thus how the «soft skills» allow the use of implicit forces that are exerted in a vertical 
way on the teachers. Such as is shown in the following textuality: "(...) if you don't arrive on time, someone is going to accuse you, it means the fact that every teacher, who has arrived late, has to work extra hours to make up for the seconds and minutes lost. Although I haven't felt censored in any aspect, imposition/ yes but about the rules because many of them are decided by consensus by the administrators and teacher are only informed and we say nothing, democracy here is equal to zero» $[4$, p. 33].

The administrative monitor is implemented by the administrative staff by means of different mechanisms of control, producing a sphere of superiority, and at the same time they are empowered over the rest of the actors of the educational community in an explicit and implicit way: "(...) there 're some ways of monitor from the administrative and pedagogical parts, but the truth ... no... I haven't felt that it's something concrete, it means, I have taught my classes since I'm here in total freedom ... nobody has gone to supervised me . . but I feel myself under control, because without warning they ask me reports from one day to another" [5, p. 43].

To analyze the code «restrictions» the work is decentralized from the physical point of view, but the power exerted on the workers is more direct. It is shown in the implementation of the contents and application of standardized assessment tools which are not appropriated for the adjacent context where teachers and students are developed. Then, it is visualized in a natural way that those contents must be applied, when the most correct would be the proposal of content totally contextualized by teachers. Thus, the empirical sampling of the interviews confirms: "(...) I think that more than the direct impositions, more than direct impositions (...) There isn't eh ... I can't see . . . a disposition to ( . . .) creativity . . . a disposition to the innovation, therefore, about teaching we 're teaching the same that twenty year ago, the discourse about contextualization is a very nice speech, but nothing else» [5, p. 23].

The differentiation of genders is fundamentally present in the absence of this problematic in the lessons planning, such as the interviewee says: «There are some problems with the gender. From the UTP, could be, because a matter of sensitivity. Maybe from the UTP can be. I've always missed this matter in the UTP, when they speak about lessons planning (...) planning together, when there's a boss and she is a woman, I think that it's more complicated for women, I couldn't say what happen, but it's not the same if the boss is a man» [6, p. 76].

The new acceptation of genders refers to the groups of practices, believes, representations and social prescriptions that appears between the members of a human group based on a symbolization of the anatomical differences between men and women [36]. The culture leaves a mark on the sexes with genders and the gender leaves a mark on perception of everything else: social, political, religious, and quotidian. According to Bourdieu [1] women and men are not a reflection of the «natural» reality, but they are the result of a historical and cultural production, 
based on the symbolization process, and as «cultural producers» develop a system of common models.

Conclusions. Through the discourse of the interviewees teachers we can discover the aspects that show the mechanisms of power that are exerted towards teachers, which show violent practices by the subjects who are at the top of the hierarchical scale towards who are on the steps at the bottom. By means of the discursive practices we can understand the components that influence in the concretization of the symbolic violence, emphasizing the mechanisms of power that are on the basis. In the educational system there is a force of symbolic control which is spread out from the top leadership towards the administrators, determining their acts, disciplining their acts, normalizing their professional action and naturalizing the exercising of power, which operates in micro-physic levels. The social categories, that unlawfully hold the privileged knowledge, maintain their interests current and active on the social network, through their processes of inculcation and cultural, economic, political and social control, which allows that the «statu quo» position is maintained and legitimized, in a certain way. Inside this circle of symbolic violence there are spied on the system of pressure and imposition that school promotes and it causes the indoctrination of the submissive or docile body, the resistance of the rebels or also the acquiescence of the self-interested in prospering throughout the system and it presents some similarity with the interests and values of the pedagogical action of the high schools.

The aspects of the Chilean educational system are ample and prosperous, and they contribute to the symbolic violence. As a matter of fact one of the more interesting myths of analyzing in Chile is about the liberal democracy. Chile is still regulated by a political Constitution promulgated in 1980, it means, during the dictatorship of Augusto Pinochet. It produces a normative context which has not reached to move forward the establishment of an authentically democratic society, and school is a reflection of this reality. According to Foucault this conception of power allows us to go further of a juridical-political vision of the sovereignty to guide the analysis towards domination, towards material operators, ways of submission, mechanisms of strategies from the techniques and ways of domination, typical of a society no democratically. In regarding to that, to study the intersubjective relationships between headmasters and teachers signified to recognize those concrete mechanisms of power that determine the symbolic interactionism in the educational institutes. This global logical, Foucault [17] calls «diagram or abstract machine». It works according to the specific principle that spread its tone to every concrete mechanisms of power.

The personal effects in teachers are shown in different ways, as well as the malaise in the professional context. Some of the teachers show lack of motivation, stress, tension in the relationships administrators- teachers, despondency and 
decrease in their creativity and innovation. All this aspects affects directly the teaching performance and job and the correct way of teaching in schools located at vulnerable contexts. Pressures from the administrative staff are categorical components that affect in the relationships of power inside the institution, tiring to teachers and restricting their aspirations, moving the power inside the school. To exert power in an institutionalized way, the symbolic violence of power is revealed, and it makes visible what is hidden under the mantle of the perception and visual acuity. The instrumentalization of power is equally accepted and it is found without any resistance from the teacher who subdue themselves under what is socially ordered and established, and that is considered acceptable for society in general. It is emphasized when the agents of the State, who impose the educational-political lineaments, are part of another field which is not the educational field. Thus, they do not have appropriate notions about what the educational field requires. They impose contents and centralize the education, which produces confusion in teacher's role, showing camouflaged violence or symbolic, instrumental and direct violence.

\section{LITERATURE}

1. Bourdieu P. La reproducción, elementos para una teoría del sistema de enseñanza. Barcelona: Laia, 1977. 286 p.

2. Foucault M. Histoire de la sexualité. T. I. París: Gallimard, 1976. 212 p.

3. Deleuze G. Crítica y clínica. Barcelona: Anagrama, 1993. 216 p.

4. Álvarez C., Blanco J., Aguado M., Ruíz A., Cabaco A., Sánchez T. Revisión teórica del burnout o desgaste profesional en trabajadores de la docencia. Revista Caesura. 1993. Vol. 2. P. 47-65.

5. Pithers R., Fogarty G. Occupational stress among vocational teachers. British Journal of Educational Psychology. 1995. Vol. 65. P. 3-14.

6. Punch K., Tuettemann E. Correlates of psychological distress among school teachers. British Educational Research Journal. 1990. Vol. 16. P. 369-382.

7. Collazo M., Martínez D. Dimensión del trabajo docente: Una propuesta de abordaje del malestar y el sufrimiento psíquicos de los docentes en Argentina. Educação \& Sociedade. 2009. Vol. 30. P. 389-408.

8. Castorina A., Baquero R. Dialéctica y psicología del desarrollo. El pensamiento de Piaget y Vigotsky. Buenos Aires: Amorrortu editores, 2005. 288 p.

9. Vigotsky L. Pensamiento y lenguaje. Buenos Aires: La Pléyade, 1947. 190 p.

10. Newman D., Grifin P., Cole, M. La zona de construcción de conocimiento: trabajando por un cambio cognitivo en educación. Madrid: Morata, 1989. $177 \mathrm{p}$.

11. Littowitz B. De-construction in the Zone of Proximal Development. Contexts for learning. New York: Oxford University Press, 1993. 215 p.

12. Lave J. La cognición en la práctica. Barcelona: Paidós, 1991. 225 p. 
13. Rogoff B. Los tres planos de la actividad sociocultural: apropiación participativa, participación guiada y aprendizaje. En Wertsch, del Río P., Alvarez, A. (eds.) La mente sociocultural. Aproximaciones teóricas y aplicadas. Madrid: Fundación Infancia y Aprendizaje, 1997. P. 111-128.

14. Engelström Y. Expansive Learning at Work: toward an activity theoretical reconceptualization. Journal of Education and Work. 2001. Vol. 14. P. 133-156.

15. Daniels H. Vygostky y la pedagogía. Madrid: Paidos, 2003. 134 p.

16. Nietzsche F. Sobre verdad y mentira en sentido extramoral. Madrid: Tecnos, 1998. $167 \mathrm{p}$.

17. Foucault M. Vigilar y castigar. El nacimiento de la prisión. 2002. Buenos Aires: Siglo XXI editores, $2002.320 \mathrm{p}$.

18. Berman M. Cuerpo y espíritu. La historia oculta de occidente. Santiago: Cuatro Vientos, $1992.410 \mathrm{p}$.

19. Husserl E. La crisis de las ciencias europeas y la fenomenología trascendental. Buenos Aires: Prometeo, 2008. 311 p.

20. Barenger D. Epistemología y metodología en la obra de Pierre Bourdieu. Buenos Aires: Prometeo, 2004. $130 \mathrm{p}$.

21. Lapassade G. Socioanálisis y potencial humanos. Barcelona: Gedisa, 1980. $240 \mathrm{p}$.

22. Cerda H. Los elementos de la investigación: como reconocerlos, diseñarlos y construirlos. Bogotá: El Búho limitada, 1998. 240 p.

23. Taylor S., Bogdan R. Introducción a los métodos cualitativos. Barcelona: Paidós, 1984. $329 \mathrm{p}$.

24. Geertz C. La interpretación de las culturas. Barcelona: Gedisa, 1973. 392 p.

25. Henning E., van Rensburg W., Smit B. Finding your way in qualitative research. Pretoria: Van Schaik Publishers, 2004. 337 p.

26. Patton M. Qualitative research and evaluation methods (3a ed.). Thousand Oaks: Sage Publications, 2002. $400 \mathrm{p}$.

27. Babbie E., Mouton J. The practice of social research. Cape Town: Oxford University Press, 2001. $370 \mathrm{p}$.

28. Terre M., Durrheim K., Painter D. Research in practice: Applied methods for the social sciences. 2a ed. Cape Town: University of Cape Town Press, 2006. 594 p

29. García Canclini N. Culturas híbridas, estrategias para entrar y salir de la modernidad. Madrid: Paidos, 2001. 410 p.

30. Núñez I. Trazos y huellas en la educación chilena en el siglo XX. Santiago: Universitaria, 2013. $215 \mathrm{p}$.

31. Foucault M. Microfísica del poder. Madrid: De la Piqueta, 1992. 189 p.

32. Sennett R. La cultura del nuevo capitalismo. Barcelona: Anagrama, 2006. 94 p.

33. Foucault M. Nacimiento de la Biopolítica. Curso en el College de France (1978-1979). Buenos Aires: Fondo de Cultura Económica, 2007. 352 p.

34. Bourdieu P. Lección sobre la lección. Barcelona: Anagrama, 1982. $64 \mathrm{p}$

35. Santos Guerra M. Las feromonas de la manzana. Revista Aletheia Mayor. 2014. Vol. 3. P. 11-18. 
36. Lamas M. El Género. La Construcción Cultural de la Diferencia Sexual. México: Grupo Editorial Miguel Ángel Porrúa, 2000. 367 p.

\section{REFERENCES}

1. Bourdieu, P. (1977). La reproducción, elementos para una teoría del sistema de enseñanza. Barcelona: Laia [in Spanish].

2. Foucault, M. (1976). Histoire de la sexualité. Tome I. París: Gallimard [in French].

3. Deleuze, G. (1993). Crítica y clínica. Barcelona: Anagrama [in Spanish].

4. Álvarez C. Blanco J. Aguado M. Ruíz A. Cabaco A \& Sánchez, T. (1993). Revisión teórica del burnout o desgaste profesional en trabajadores de la docencia. Revista Caesura, 2, 47-65 [in Spanish].

5. Pithers, R. \& Fogarty, G. (1995). Occupational stress among vocational teachers. British Journal of Educational Psychology, 65, 3-14.

6. Punch, K., Tuettemann, E. (1990). Correlates of psychological distress among school teachers. British Educational Research Journal, 16, 369-382.

7. Collazo, M., Martínez, D. (2009). Dimensión del trabajo docente: Una propuesta de abordaje del malestar y el sufrimiento psíquicos de los docentes en Argentina. Educação \& Sociedade, 30, 389-408 [in Spanish].

8. Castorina, A., Baquero, R. (2005). Dialéctica y psicología del desarrollo. El pensamiento de Piaget y Vigotsky. Buenos Aires: Amorrortu editores [in Spanish].

9. Vigotsky, L. (1981). Pensamiento y lenguaje. Buenos Aires: La Pléyade [in Spanish]

10. Newman, D., Grifin, P., Cole, M. (1989). La zona de construcción de conocimiento: trabajando por un cambio cognitivo en educación. Madrid: Morata [in Spanish].

11. Littowitz, B. (1993). De-construction in the Zone of Proximal Development. Contexts for learning. New York. Oxford University Press.

12. Lave, J. (1991). La cognición en la práctica. Barcelona: Paidós [in Spanish]

13. Rogoff, B. (1997). Los tres planos de la actividad sociocultural: apropiación participativa, participación guiada y aprendizaje. En Wertsch, del Río, P., Alvarez, A. (eds.) La mente sociocultural. Aproximaciones teóricas y aplicadas. Madrid: Fundación Infancia y Aprendizaje [in Spanish].

14. Engelström, Y. (2001). Expansive Learning at Work: toward an activity theoretical reconceptualization. Journal of Education and Work, 14, 133-156. doi: $10.1080 / 13639080020028747$

15. Daniels, H. (2003). Vygostky y la pedagogía. Madrid: Paidos [in Spanish].

16. Nietzsche, F. (1998). Sobre verdad y mentira en sentido extramoral. Madrid: Tecnos [in Spanish].

17. Foucault, M. (2002). Vigilar y castigar. El nacimiento de la prisión. Buenos Aires: Siglo XXI editores [in Spanish].

18. Berman, M. (1992). Cuerpo y espíritu. La historia oculta de occidente. Santiago: Cuatro Vientos [in Spanish].

19. Husserl, E. (2008). La crisis de las ciencias europeas y la fenomenología trascendental Buenos Aires: Prometeo [in Spanish] 
20. Barenger, D. (2004). Epistemología y metodología en la obra de Pierre Bourdieu. Buenos Aires: Prometeo [in Spanish].

21. Lapassade, G. (1980). Socioanálisis y potencial humanos. Barcelona: Gedisa [in Spanish].

22. Cerda, H. 1998. Los elementos de la investigación: como reconocerlos, diseñarlos y construirlos. Bogotá: El Búho limitada. Introducción a los métodos cualitativos [in Spanish].

23. Taylor S., Bogdan, R. (1984). Introducción a los métodos cualitativos Barcelona: Paidós.

24. Geertz, C. (1973). La interpretación de las culturas. Barcelona: Gedisa [in Spanish].

25. Henning, E., van Rensburg, W., Smit, B. (2004). Finding your way in qualitative rese arch. Pretoria: Van Schaik Publishers.

26. Patton, M. (2002). Qualitative research and evaluation methods (3a ed.). Thousand Oaks: Sage Publications.

27. Babbie, E., Mouton, J. (2001). The practice of social research. Cape Town: Oxford University Press.

28. Terre, M., Durrheim, K., Painter, D. (2006). Research in practice: Applied methods for the social sciences ( $2 \mathrm{a}$ ed.) Cape Town: University of Cape Town Press.

29. García Canclini, N. (2001). Culturas híbridas, estrategias para entrar y salir de la modernidad. Madrid: Paidos [in Spanish].

30. Núñez, I. (2013). Trazos y huellas en la educación chilena en el siglo XX. Santiago: Universitaria [in Spanish].

31. Foucault, M. (1992). Microfísica del poder. Madrid: De la Piqueta [in Spanish].

32. Sennett, R. (2006). La cultura del nuevo capitalismo. Barcelona: Anagrama [in Spanish].

33. Foucault, M. (2007). Nacimiento de la Biopolítica. Curso en el College de France 1978-1979). Buenos Aires: Fondo de Cultura Económica [in Spanish].

34. Bourdieu, P. (1982). Lección sobre la lección. Barcelona: Anagrama [in Spanish].

35. Santos Guerra, M. (2014). Las feromonas de la manzana. Revista Aletheia Mayor, $3(3), 11-18$.

36. Lamas, M. (2000). El Género. La Construcción Cultural de la Diferencia Sexual. México: Grupo Editorial Miguel Ángel Porrúa [in Spanish].

Хуан Гільсрмо Мансілла Сепульведа, професор, факультет освіти, Католицький університет Темуко, Чилі

Клаудіа Андреа Хуакіан Біллеке, професор, факультет освіти, Католицький університет Темуко, Чилі

Хуан Гільермо Естай Сепульведа, професор, факультет освіти, Католицький університет Темуко, Чилі, факультет освіти, Адвентистський університет, Чилі 
Герман Морено Леіва, професор, факультет медичних наук, Американський університет, Чилі

\section{ІНТЕРСУБ' СКТИВНІСТЬ І ВЛАДА В АДМІНІСТРАТИВНОМУ УПРАВЛІННІ ОСВІТНІМИ ЗАКЛАДАМИ}

Постановка проблеми. Механізми влади, що їх використовуе керівнищтво икільних навчальних закладів, непомітно підсилюють кількість символічного насилля як на рівні дискурсу, так і в повсякденній икільній практиці. В освітній сфері інтерсуб' 'сктивні відносини набувають практичної реалізації, часто нав'язуючи небажані дї̈ та створюючи невидимий паноптикум. Проблема влади також актуалізуе питання застосування дисиипліни на людських тілах та відповідної їньої покірливості, ио с результатом обов'язкового розуміння норм, правил, дисципліни тощо.

Аналіз останніх досліджень і публікацій. Концептуальна основа статті корелюе з науковими публікаціями в галузі сочіокультурних досліджень (Л. Виготський), соціального конструювання знань, компетенцій та ідентичностей (Д. Ньюман, П. Гріфін, М. Кол, Д. Літтовіти), третього покоління теорій активності (Й. Енгельстром, Х. Деніелс), теорії габітусу та символічного насилля (П. Бурдьє), а також з традиційними положеннями теорії влади, викладеними у працях Ф. Ніџще, М. Фуко, М. Бермана та іниих авторів.

Формулювання цілей. Автори виходять із того, що будь-який прояв влади має на меті з витонченим удаванням нав 'язати людям смисли, так само як і відношенна сили, виправдане нею самою. У свою чергу, це підкреслюе символічність пролвів влади для інтерсуб 'сктивних відносин, цо існують між представниками певної спільноти. Мета дослідження полягає в показі механізмів влади, що ӥх систематично використовує керівництво для контролю за навчальними та адміністративними діями у навчальних закладах, розтамованих у сочіокультурних регіонах із високим ступенем сочіально-економічної вразливості.

Виклад основного матеріалу. У статті викладені результати дослідження адміністративного керівниџтва освітніми закладами з використанням можливостей герменевтичної методології. Герменевтична парадигма дозволяс вивчити динаміку влади, що складає підвалини викладацького дискурсу щооо асиметричних інтерсуб 'єктивних відносин, які виникають між дирекцією та вчителями середніх икіл у регіоні Арауканія на півдні Чилі. Учасниками дослідження стали 14 директорів икіл та 48 учителів. Збір даних здійснювався за допомогою фокус-груп із директорами шкіл та докладних інтерв'ю з учителями. Обробка даних здійснена у прочесі відкритого та мережевого кодування з використанням програмного забезпечення Atlas Ti 6.2. Отримані дані свідчать про існування інтерсуб 'єктивних відносин, цо підтверджують здійснения влади та контроль над учителями з боку директорів. Учасниками дослідження визнані систематичні дискурсивні практики символічного насилля, що негативно позначається на професійних якостях учителів. 
Висновки. Тиск із боку адміністративного персоналу стає одним із вирімальних факторів професійного життя вчителів. Символічне насилля влади виявляється на інститучіональному рівні, обумовлюючи підкорення вчителів тому, щзо є сочіально впорядкованим, встановленим та вважається прийнятним для суспільства в иілому. Агенти держави, не будучи представниками освітянської сфери і не маючи належних уявлень про освітянську сферу, нав 'язують освітньо-політичні стратегії, централізують освіту, трансформують роль учителя, вдаючись до символічного або інструментального насилля.

Ключові слова: інтерсуб' 'сктивність, середня икола, влада, утиски, учителі.

Хуан Гильермо Мансилла Сепульведа, профессор, факультет образования, Католический университет Темуко, Чили

Клаудиа Андреа Хуакиан Биллеке, профессор, факультет образования, Католический университет Темуко, Чили

Хуан Гильермо Эстай Сепульведа, профессор, факультет образования, Католический университет Темуко, Чили, Адвентистский университет, Чили

Герман Морено Лейва, профессор, факультет медицинских наук, Американский университет, Чили

\section{ИНТЕРСУБЬЕКТИВНОСТЬ И ВЛАСТЬ В АДМИНИСТРАТИВНОМ УПРАВЛЕНИИ ОБРАЗОВАТЕЛЬНЫМИ УЧРЕЖДЕНИЯМИ}

В статье представлены результаты исследования, осущественного в рамках герменевтической парадигмыл. Данная парадигма связана с динамикой власти, лежащзей в основе рассуждений учителей об асимметричных интерсубъективных отночениях, которые возникают между директорами и учителями средних икол из региона Араукания на юге Чили. Интерсубъективность отноиений свидетельствует о том, что директора осуществляют власть и контроль над учителями. Кроме того, в механизмах, разработанных административной организаңией, имеет место насилие. Участники признали систематическую дискурсивную практику символического насилия, которая наносит ущерб их профессиональным качествам.

Ключевые слова: интерсубъективность, среднял икола, власть, притеснение, учителя. 